\title{
The Invention of Perspective and the Transition from the Sacred to the Religious
}

\author{
Rafael García Sánchez
}

check for

updates

Citation: García Sánchez, Rafael. 2021. The Invention of Perspective and the Transition from the Sacred to the Religious. Religions 12: 818. https://doi.org/10.3390/rel12100818

Academic Editors: Manuel Lázaro Pulido and Ricardo Piñero Moral

Received: 14 July 2021

Accepted: 24 September 2021

Published: 28 September 2021

Publisher's Note: MDPI stays neutral with regard to jurisdictional claims in published maps and institutional affiliations.

Copyright: (C) 2021 by the author. Licensee MDPI, Basel, Switzerland. This article is an open access article distributed under the terms and conditions of the Creative Commons Attribution (CC BY) license (https:// creativecommons.org/licenses/by/ $4.0 /)$.
School of Architecture and Building Engineering, UPCT-Politechnical University of Cartagena, 30201 Cartagena, Spain; rafael@sgbarquitectos.es

\begin{abstract}
Many historical events and scientific and artistic discoveries took place at the twilight of the Late Middle Ages and the beginning of the Renaissance. The great majority of them enabled the birth of individualism and the objectification of reality. This was decisively influenced by the devaluation of the oral and the prioritization of the visual. The priority of sight as a sovereign form of knowledge had in the invention of perspective one of its most unquestionable foundations. All of this caused a change in mentality that, in the field of aesthetics, gave rise to a new conception of the artist and his authorship and, undoubtedly, to the prevalence of the religious and devotional over
\end{abstract} the sacred.

Keywords: perspective; geometry; religious; saint; Renaissance

And the Gods gathered and said to themselves: Men can see almost everything. They look too much like us.

Then ...

\section{Introduction: Modernity and the Prioritization of Sight}

One of the ways for us to distinguish between the Western Middle Ages from Modernity is to appeal to their concepts of work, world, reality and image. The former is the time of craftsmen, rules, canons and finally, guilds. The latter is the time of inventors, artists and, especially, freedom. Craftsmen create instruments; inventors create devices and machines. Ortega said that the medieval craftsman was a technician and a worker at the same time. On the other hand, the modern technician was not just a worker anymore, but he was the person in charge of planning and theorizing (Ortega y Gasset 2015, pp. 123-29). His machines and devices, such as the telescope, perspective and doubt, acquired an extraordinary relevance. Since they were deemed "Archimedean points" (Arendt [1958] 1998, p. 267), they served to extrinsically secure the physical and visual reality and enabled the production of the objects and the phenomena that were observed.

From another point of view, the Middle Ages can be undoubtedly considered as a period of time more pious than the Modern Age. If we understand "piety", as María Zambrano would say, as the capacity to properly deal with the divine (2019, p. 243), i.e., to "feel the other as such, without schematizing it in abstractions" (Zambrano 2019, p. 255), the Modern Age was much less pious than the Middle Ages. We can precisely use this concept of pietas to explain why the world was, to medieval people, what could be heard and seen, and on the other hand, to modern people it was just what could be seen. It would not be accurate to affirm that, seen as a whole, the Middle Ages rejected the Visual Arts. As Uspenski has noted, the sacred and iconic image enjoyed the same prestige and dignity as that of the Writing: "Therefore, the image belongs to the same nature of Christianity because this is not only the revelation of the Word of God but also the Image of God manifested by the God-man (Uspenski 2013, p. 38)." 
Certainly, those sacred images were lost mainly in the West, due to cultural density due to the coming of the Modern Age and the paganization of culture. In this respect, Belting is quite right when he asserts that one of the differences between the Western Middle Ages and the Modern Age is the difference existing between a cult image and a work of art (2021, pp. 24-25). The medieval cult image and the icon have a public aura and power that only make sense in the liturgical sphere: "Therefore, the Sacred Art is liturgical by its own nature" (Uspenski 2013, p. 148). In turn, the modern work of art frequently became a private object of enjoyment and pleasure to the eye, and it was released from its cultic scope or vital context (Sitz im Leben). In this regard, Modernity is much more aesthetic than the Middle Ages. The cult image is shown, "it is a confession of the truth, a profession of faith" (Uspenski 2013, p. 148), while the work of art is displayed, as Benjamin would say (2002, p. 106).

Although the priority of sight over hearing is present within modern Catholic genetics, it is not original to that time. It is well known that, since time immemorial, at least from the scope of love and wisdom, the bond between sight and intelligence is absolutely unquestionable. Heraclitus already stated in the sixth century BC that "eyes are more exact witnesses than ears" (Heráclito 2008, fr. 6(101a), p. 130). Plato tells us in Timaeus that the eye was the first organ created by Gods (Plato 2008, p. 45b). According to Aristotle, the noblest human activity that generates the most joy and pleasure (Aristotle 2019, XII $\Lambda, 1072 \mathrm{~b}$ ) is that that most closely resembles the divine activity: contemplation (Aristotle 2009, X, 8, 1178b). As we know, in the Greek language "to know" is "to have seen", not for nothing have the words eídenai (to know) and eidos (form) the same root: to see. It should be noted that the expression "I see!" or the question "Can you see it?" properly illustrate to what extent "seeing is knowing". To know something consists of rescuing it from penumbra or darkness. Something dark cannot be seen. Something shady is, we could say, what cannot be understood. It is not surprising that one of the centuries that Modernity gave birth to was the Age of Enlightenment, and, as Zubiri states, that the priority granted to sight for so many centuries is such that "what is not seen is considered, eo ipso, understandable" (Zubiri 1980, p. 104).

We are aware that many religions have considered God as the all-seeing being. God is the being that no one can hide from. Philosophers from almost all eras were quite right when they asserted that "knowing is seeing", and that seeing is what God does, he who knows everything. In the Book of Proverbs and the Book of Psalms, we can read: "The eyes of the Lord are in every place, watching the evil and the good" (Prov., 15, 3); "His eyes watch the nations, let not the rebellious rise up against him" (Psalm, 66, 7). To Nicholas of Cusa, a German philosopher of the 15th century that had to know the first graphic testimonials of scientific perspective, the point of view of man was not in any way comparable to that of God (de Cusa 2009). The gaze of God is infinite, absolute and omnipresent. On the other hand, the human gaze is partial and relative. Right at the beginning of De visione Dei, he states "Deus etenim, qui est summitas ipsa omnis perfectionis et maior quam cogitari possit, theos ob hoc dicitur, quia omnia intuetur" (2009, I, p. 69). This is precisely why it is not surprising that one of the ways to depict God in religious iconography, including in Christianity, in particular since the Renaissance, is through the image of a provident all-seeing eye. In this regard, see Supper at Emmaus by Jacopo da Pontormo (1494-1557), The allegory of God's Eye by Jan Provost (1465-1529) and The eye of God by El Bosco (ca. 1450-1516).

For a modern individual, an object is what can be seen or what can be looked at. That is why the most tenacious determination of the Modern Age was to expose as much reality as possible or, as Heidegger would say, to display or to evidence what is real. Few words as the word "evidence" are so representative of a period of time. Not for nothing is the evident that what can be undoubtedly seen, without any shadow of suspicion. What is an object to an individual? What can be seen in its entirety. What does understanding the world and reality involve? To see them, and in the end, to be able to depict them in an image. Until the invention of a method guaranteeing that the depiction was the true image of what was seen, neither the world nor reality were an actual object to an individual. 
It turns out that to see, to rigorously depict what is seen and to objectify are correlative terms to modern individuals. Hence, the great importance that the invention of perspective had to them. The objectification of reality needed its view and accurate depiction. Through the rest of the senses, such as touch, taste, smell and hearing, objectification was not as scientifically possible, because as we know, neither what is touched nor what is tasted or smelt or heard can be measured with the level of mathematical and geometric accuracy and rigour as that which happens with what can be seen. The expression "well seen" still enjoys great prestige. Other expressions, such as "to have a nose for", "to have taste", "to be tactful", refer to other practical qualities of the individual, but not to knowledge. That certainty, the certainty given by the sight, is the certainty that artists managed to guarantee at the beginning of the Modern Age. Their indefatigable efforts reached their peak when the subsequent idealism managed to reduce reality to "a unique, visible horizon, to absolute knowledge" (Zambrano 2019, p. 230).

\section{The Invention of Perspective}

The concept of perspective is not a Renaissance invention. There are traces in the ancient world, from the book Optics by Euclid in the fourth century BC to the Vitruvian treatise of the first century BC. The second of the definitions offered by Euclid in his treatise on vision established that, "and that the form of the space included within our vision is a cone, with its apex in the eye and its base at the limits of our vision" (Euclides 1945, p. 357). Additionally, when Vitruvius refers to "scenography" (Vitruvio 1993, p. 9), he understands it as the use of a sort of image in perspective, a "mise-en-scène" (Arnau 1987, p. 117), that will allow the architect to visualize the effect of the designed building. This scenographic or perspective previsualization is what will result in subtle formal deformations that the skilful and prudent author must introduce in order to guarantee a pleasant effect. It is true that the use of scenography was already common in Greek theatre performances, which were aimed at creating a simulation of reality as credible as the visual illusionism could offer. The Greek architect, when checking the visual effect by means of foreshortened drawings, behaved as a spectator (theorós) that enjoyed the theatre (theatron): the place to see reality by watching it (García Sánchez 2020, pp. 70-75). The same can be applied to the painters of the Pompeian villas, who were also specialists in the creation of visual simulations and spatial illusionism (Florenski 2002, p. 211). During the Middle Ages, theatre representation became sacralised, but it did not disappear. Therefore, the knowledge of certain procedures of simulation and visual illusionism would be used by the set makers (Pernoud 2010, p. 55). However, neither the Greeks, Romans nor Medieval men went further than the scientific knowledge of perspective. They did not do so because, according to Florenski, they were not interested and did not want to replace reality with any kind of appearance. The icon painters confirmed and represented reality, which is why they hated the illusionism of perspective, a mechanism of the production of appearances, in the Platonic sense of the term.

"The Middle Ages, which made a decisive break with the goals of illusionism and took on the task of creating, not simulacra, but symbols of reality, seems a decline. Finally, even here the art of the New Age, that began with the Renaissance and straightway decided, by a silent wink and by some current of mutual agreement, to substitute the construction of simulacra for the creation of symbols ( . . . )" (Florenski 2002, p. 215).

During the Renaissance, interest in the creation of spatial simulations did not decrease, rather it grew stronger. There are many cases of artists and architects of the Renaissance that carried out theatre scenes or urban perspectives. We know that Brunelleschi created many sets, the best one of which was undoubtedly the set created in 1422 for the performance of the Ascension of Christ at the Church of Santa Maria del Carmine in Florence, let alone the scenography that he carried out at San Felice in Piazza. It is known that Alberti created some sets that, unfortunately, were not preserved. We know that the treatises of Serlio and Vignola included many pages about scenography. We find singularly revealing the three 
urban panoramas of Urbino, dated in 1470 approximately and created at the request of Federico da Montefeltro (Belting 2011, pp. 185-204).

There is no doubt at all that the scientific use of perspective, based on a geometric and accurate methods, as mathematics, would not take place until the advent of Renaissance culture, especially attracted to the creation of spatial illusions. Although the concept of space has generated an enormous enchantment and fascination since time immemorial, it was in the Renaissance, and undoubtedly, in the Baroque when it reached one of its highest peaks. Cartesianism would even insist that there was nothing more real than space, that there was no more error-free science than geometry and arithmetic, and that there was nothing more intelligible than expanse.

Strictly speaking, geometry and perspective owe a lot to medieval scientists and optics scholars, both Catholic and Muslim. It would be idle to prepare a detailed list of those authors whose research field was focused on the study of vision and optics prior to the Renaissance. It is sufficient here to mention the Muslim mathematician Alhazen (965-1040) (Lindberg 1976, pp. 1-17, 57; Belting 2011, pp. 26-27), the bishop of Lincoln, Robert Grosseteste (1175-1253), the English Franciscan Roger Bacon (1214-1292) (Lindberg 1996, pp. xxv-xxxvii) and the abbot of Canterbury, John Peckham (1225-1292), in order to realize that during the Renaissance the immense field of scientific research, that was simply called optics by researchers in the Late Middle Ages, started to be known as scientific perspective (Lindberg 1983, pp. 338-39).

If we focus on the desire for accuracy and precision that settled in European, and in particular, Italian culture in the late 13th century, the existence of which extends to present time, evidence suggests that Brunelleschi (1377-1446) was the inventor of "prospettiva" (Manetti 1976, p. 55) (perspective), although it was Alberti (1404-1472) who further developed it from the scientific point of view into the field of visual arts. Artistic Modernity was precisely baptized in a baptistery, in Florence, in the first quarter of the 15th century. With a square board $(30 \mathrm{~cm}$ maximum) and a flat mirror, Brunelleschi founded the scientific perspective by matching the painting to reality. The image was scientifically objectified and ceased to be just a mere appearance or illusion.

The purpose of the invention of scientific perspective was no other than to find an accurate and univocal method (scienza) for "le diminuzioni ed acrescimenti" (reductions and enlargements) (Manetti 1976, p. 55) allowing the observer to accurately represent what he saw at a certain distance and at a certain height. Additionally, here, "accurate method" must be understood as the set of geometric and mathematical operations allowing for guaranteed accuracy of depictions from an Archimedean point or a point extrinsic to the very nature. That Archimedean point, the perspective, is what made it possible for the gaze to become an objective image (Belting 2011, p. 267). It should be noted that we refer to the accuracy of depictions and not of reality, because it is no secret that the depiction of reality is not the same as the very reality. Indeed, the scientific perspective satisfied a desire for spatial rigour and certainty. Nevertheless, we must not forget that what the author depicts in the pictorial window is just an image of what he looks at, but this is not the truth of what has been seen, strictly speaking. We should note here the singular difference between the icon and the Renaissance painter:

"Illusionism is characteristic of the subjectivism of modern man, whereas nothing could be further from the intentions and thoughts of medieval man, with his roots in antiquity, than the creation of simulacra and a life spent among simulacra" (Florenski 2002, p. 217).

\section{Subjectivism, Mysticism and Nominalism}

From the historical point of view, it is true-but not rigorously definitive- that Modernity was exclusively inaugurated by the invention of perspective. It remarkably influenced and even encouraged other areas of knowledge, from philosophy and ontology to physics and other experimental sciences, let alone the enormous advantage that it implied for war strategies. However, it is apposite to briefly examine some historical aspects of the 
end of the Middle Ages, because some main issues of the Renaissance could not be explained without them. It is well known that the centre of gravity of Modernity is the subject, as an autonomous and independent axis. It celebrates the end of guild and magisterial authority and leaves the moorings of the ego "brakeless" (Maritain 2006, p. 20), with no rams, and free, in a vast field of spiritual and cognitive, natural and sensitive activities. In the 19th century, Burckhardt highlighted the importance of exaltation of individuality ("the development of the individual") that took place during the Italian Renaissance (Burckhardt 1966, p. 70 ss). In continuity with the foregoing, Heidegger stressed that "Certainly the Modern Age has, as a consequence of the liberation of man, introduced subjectivism and individualism" (Heidegger 2018, p. 72). Panofsky verified an identical situation when asserting that Modernity resulted in "an extension of the domain of the self" (1991, p. 68). This conquest started to be planned in various fields, which we will briefly mention, and that became part of the Western cultural history under the following titles: individualism and subjectivism, mysticism and nominalism.

There is no doubt that some authors would have authority to affirm, not without reason, that the Middle Ages could be considered finished when the figure of the Pope, the moral and religious highest authority, was undermined. We could even say that autonomy of the individual with regards to the papal authority reached its highest peak when the Christian king, Philip IV of France, due to reasons that cannot be mentioned now, not only decided to disobey the guidelines of the Holy Father, but also to plan his murder. Indeed, when this plot was hatched against Boniface VIII in the year 1303, the Middle Ages could be considered finished. Those who affirm that Modernity was founded on the end of authority, tradition, custom and magisterium are quite right.

Furthermore, prior to these events, the Fourth Lateran Council (1215) established the birth of individual confession. This highlighted the importance of self-knowledge (Putallaz 1991) and individual conscience, along with the individual canonical penalty, individual penitence and, finally, individual holiness and salvation. It is no coincidence that-from that moment - the most psychological, individual and private features started to stand out. All of this had an influence on personal hygiene, on the appearance of the individual room, on the individual plate, on the invention of mirrors, and on the proliferation of personal names and nicknames that highlighted the singular personality of each individual. The dawn of autobiographies, diaries and individual and silent reading in the solitude of a private room took place before the Renaissance. Alain de Libera (2015) rightly notes that we should not wait for the Modern Age coming to find traces which outline the silhouette of the modern man.

It was at this time, precisely because the individual and psychological features of the subjects were highlighted, that there was an increase in the number of canonizations and beatifications (Morris 1972, p. 283), given that private and intimate life was better-known and became increasingly public. All these aspects, from the most spiritual to the most social, gave Modernity a particular physiognomy: individuality and singularity. It is not surprising that, during the Renaissance, individuality and singularity were undoubtedly demanded and bought, which was quite strange to the medieval culture.

During the Middle Ages, there were no works of art, but cult images, as Guardini, Uspenski and Belting would say. Works of art are individual creations for an individual and private use; cult images were creations for a cultic and public use. It is well known that in the long medieval period there were no individual authors, but authorities. With the exception of some Byzantine authors that were proud of their works and left traces of their authorship, it is common knowledge that works of art were not usually signed. However, they could bear the seal of a collective author, the guild or workshop that had created them (Florenski 2002, p. 134) ${ }^{1}$. Nevertheless, the Modern Age is not the time of authorities, but of authors. With the exaltation of individuality, art patrons and sponsors demanded singularity, authorship and genius, which were factors that started to influence the revaluation of works of art. Modernity is not the time of guilds or collective and anonymous works but 
that of geniuses. Ortega was right when he said that "brilliant are those creations that can have issue, that are living wombs of culture" (Ortega y Gasset 2016, p. 109).

The demand for works of art was simultaneously a demand for professional virtuosity, for singular capacity, for skills and expertise of a person that has become an author thanks to facilità, ease and grazia. The signature and authorship of those who had to deal with difficultà increased in value, and this is why author's art with its own style was traded and marketed, which is typical to times that extol fame and individuality. The importance acquired by the author's singular authorship prevailed over the quality of materials to be used, over the theme, over the size of the work, etc. The fact was that genius and singularity were unrivalled, and exhibition power prevailed over cult power. Not even the finest material, gold, could compete with mastery in the use of a paintbrush, with the skills of the author, a word that, according to Ortega, comes from auctor, which means "the one that increases"; not for nothing was this word used in the Latin language to refer to a person that conquered new territories for the empire (2016, p. 78). The centrality of authorship and of free interpretation of the rules or standards, which-instead of blinding them-took them to a full unprecedented luminosity, properly explains that we are witnessing the birth of the concept of intellectual property. So said Von Martin:

"The idea that an author or an artist could claim any property rights in his works arose only with the new wish to be original, to be a "uomo singolare" or "unico. It was the idea of the self-conscious author, demanding in Petrarca's words that "everyone should write his own style" in order to have a personal influence on others". (Von Martin 1944, p. 40).

Panofsky added mysticism, nominalism and subjectivism to the overflow of individualism (1976, pp. 12-16). Subjectivism is inextricably related to the importance given by this period to the expansion of the ego and interiority (Putallaz 1991; de Libera 2015). Panofsky used the word intuitus, so celebrated by Ockham 's nominalism and by Eckhart's mysticism (1260-1327), in order to refer to the extremely private and internal experience, the most intimate and reserved: intuitus mysticus. This kind of experience is, as Eckhart would say, the experience that results from the birth of the Son of God inside the individual thanks to the grace. However, we must not forget that intuitus also consists of staring at something, and hence in-tueor, to look inside and from inside. We must not be surprised that Descartes, one of the founding fathers of Modernity, used this word to refer to the first of the three characteristics of the angelic knowledge: intuitive, innate and independent of things (Maritain 2006, p. 55). Likewise, it is not strange that Luther, another one of the most pre-eminent drivers of Modernity, strenuously defended individuality and interiority, the intimate relationship with God, without the mediation of any authorities, traditions, customs or, undoubtedly, many of the sacraments.

The invention of perspective enhanced geometry, which became the paradigm of all areas of knowledge. Thanks to geometry and arithmetic, artists could objectify reality as regards its quantifiable and measurable aspects. Indeed, quantitative and extensive reality can be measured. Knowing is seeing, as the archaic and ancient Greeks used to say. In the Modern Age, knowing is seeing and, undoubtedly, measuring. Additionally, perspective was invented to aid the individual that wanted to measure reality in order to dominate it. As Panofsky said, this is precisely why "the most characteristic expression of this subjectivism is the emergence of a perspective interpretation of space which, originating with Giotto and Duccio, began to be accepted everywhere since 1330-1340" (1976, p. 16). So, the exaltation of the ego, of the point of view of the individual, was correlative to the great respect for geometry and mathematics. For these disciplines, the only legitimate characteristics of reality are those that can be measured and those that have an expanse. Since then, space (the subject matter of geometry) acquired great relevance from the epistemological point of view. In Perspective as Symbolic Form, Panofsky asserted that this method of knowledge based on the geometric science will simply reduce phenomena and qualities to mere quantifiable categories related, whether we like it or not, to the individual and to his point of view. So, thanks to perspective, subjectivity could be objectified, and this paradox was apparently the basis of Modernity. 
“( .. ) Perspective subjects the artistic phenomenon to stable and even mathematically exact rules, but on the other hand, makes that phenomenon contingent upon human beings, indeed upon the individual: for these rules refer to the psychological and physical conditions of the visual impression, and the way they take effect is determined by the freely chosen position of a subjective point of view" (Panosfky 1991, p. 67).

Pável Florenski highlights the same risk when he affirms that "A perspectival representation of the world is one of the countless methods possible for establishing the aforesaid correspondence, but it is a method that is extremely narrow, extremely limited, hampered by a host of supplementary conditions that define its potential for application and the limits to which it can be applied" (2002, p. 261).

Mysticism was not strange to cultural centrality of the individual either. About modern mysticism, we could say that it was just the correlate of cognitive subjectivism in the religious and spiritual sphere. It emerged with singular strength at that time and limited the religious, community and collective experience to the kingdom of the private and psychological, of internal images, in short, to the space of the intuitus mysticus. The individuality of the mystic experience takes to the extreme the cognitive, sensorial, spiritual and psychological singularity of the relevant person. This is a maximum "subjective moment" (Belting 2021, p. 554). Somehow, mysticism makes the particular vision of God prevail over the general and public vision of the community of believers. The prevalence of the mystic point of view is unrivalled, while the mystic has immediately seen the entirety of reality, as if he had seen it through the eyes of God (Panikkar 2008, pp. 45, 69).

It remains for us to highlight the strength of nominalism. Nominalism can be considered as the subjective version of knowledge, the substantification of a form of general knowledge or knowledge in absolute terms. With nominalist activity, the intuitus of the individual continued to be in full force and effect. We owe to Umberto Eco (1932-2016) a sort of synthesis of the theory of knowledge in nominalist terms. When the Italian philosopher and semiologist finished his famous novel The Name of the Rose, he put some extremely nominalist verses into the mouth of William of Baskerville, a clear reference to William of Ockham (1300-1349). Indeed, Eco paraphrases some well-known verses of the Benedictine abbot of the 12th century, Bernard of Cluny, which read: "Nunc ubi Regulus aut ubi Romulus aut ubi Remus?/Stat Roma pristina nomine, nomina nuda tenemus". Eco borrows the last verse and replaces Roma with rosa: "stat rosa pristina nomine, nomina nuda tenemus" (Eco 1992, p. 471). His intention is quite clear, since he tries to evidence the impossibility of a universal and absolute knowledge: "The ancient rose remains by its name, naked names are all that we have". Nominalism will defend the sensitive knowledge captured by notitia intuitiva (by the senses) and by the internal experience (Panosfky 1976, pp. 12-15), intueor, and will defend it against abstract knowledge, which knows reality on the fringes of its specification. Therefore, the truth can only be said about what is perceived by the senses, i.e., the specific and individual thing: "stat rosa pristina nomina, nomina nuda tenemus".

As we can see, the end of the Middle Ages and the beginning of the Renaissance can be synthesized in the birth of individualism and subjectivism with their religious and epistemological derivatives. From among all of them, probably the most uncontrollable strength of this period emerged, which according to Lortz was the strength of "national particularism" (Lortz 2008, p. 24) that gave birth to the first forms of nationalism, something that we cannot deal with at this moment.

In summary, at the dawn of Modernity, everything seemed to orbit the individuality of the subject and his point of view. The modern individual, as a transcendental axis, made the entirety of reality orbit him. Reality has become something seen by and projected from me, which makes the gaze become the sovereign instance over the world (Belting 2011, p. 267). Additionally, that is precisely why Heidegger will assert that this period is The Age of the World Picture (2018, pp. 63-90) whose main characteristic is that the individual converts his gaze into an image, since "man becomes that being upon which all that is, is grounded as regards the manner of its Being and its truth. Man becomes the referential centre of beings as such" (Heidegger 2018, p. 73). All this would end medieval theocentrism, leading to 
a cultural anthropocentric dimension, which perfectly fits-as a glove on the hand- into the scientific perspective. Florenski states this as follows "perspective is a method that of necessity results from a Weltanschauung in which the real basis for half-real, things-notions is admitted to be a certain kind of subjectivity, which is itself devoid of reality" $(2002$, p. 264).

\section{Perspective: Certainty and Accuracy}

Prior to the Renaissance, from the most primitive arts, the funeral Egyptian masks, the Hellenistic portraits, (Florenski 2010), the Byzantine icons (Uspenski 2013; Belting 2021), to the panels of Romanesque and Gothic altarpieces, everything that was depicted seems to be painted "close up", as Ortega would say (2016, p. 195). Everything, both close and distant things, is shaped and defined with the same accuracy and clarity with which an object would be drawn in the foreground. The painter's gaze does not seem to stray from things, and he often depicts distant things with the accuracy of the nearest ones. Given that this view mode prevents from seeing the surroundings, the depiction lacks a point of view or, as Ortega asserts, we could say that there are as many points of view as there are objects (2016, p. 195) or as Florenski would say, it is a representation with "polycentredness" (2002, p. 204). Everything seems to have the same dignity, with the exception of the recourse to the hierarchical perspective or the reverse perspective: bigger that which is more important and smaller that which is less relevant, as happens with icons in medieval cult images, and currently with political propaganda images, from the most long-established to the most liberal and democratic ones.

It is well known that things have their qualities and their measurements, but there is a certain gap between what is known and what is seen. In other words: not everything that is and can be seen can be looked at. There are two reasons. Firstly, eyes see what they can see and there are aspects and qualities of reality that are beyond human vision conditions. Secondly, there is always a limit. There are things that must not be looked at; there are limits that the gaze must not and cannot cross. Frontal and unlimited gaze was frowned upon. The ancients knew that well and left the testimonials of Narcissus and Actaeon. As we know, the latter bent his indiscrete gaze toward the virgin Diana when she was having a bath, and that is why he was punished. The case of Orpheus is also singularly illustrative: he looked at Eurydice and crossed the limit between life and death, and that is why he lost her again.

Now, let's go back to the first reason. Fidelity to reality is not fidelity to what things are, but to the way in which they deal with the sensible experience. Therefore, it was necessary to secure what had been captured by the senses, and that is what the Renaissance artists did with the geometric discovery of perspective, based on mathematics. Hegel was right when he said that the Renaissance was extremely captivated by the eagerness to discover (Hegel 1989, p. 649). The invention of scientific perspective was one of those great discoveries. It was probably the most important find at the dawn of Modernity. We consider it as a highlight of artistic research to such an extent that we could say that in the Renaissance, being an artist was to be a scientist, since an artist was someone that knew how to measure. A person could measure, if he knew how to look and rigorously depict what had been seen. Furthermore, an artist was a person that could master the things he looked at and that considered the space as a mathematical magnitude that facilitated the depiction of accurate data of reality.

When imagining the Renaissance artists at their bottega, we would make a mistake if we believed that their work was just a subsequent version of the workshops of Greek and Roman craftsmen or of the guild circles of the late Middle Ages. Absolutely not. Unlike all of them, the Renaissance artist and, more precisely, the painter transformed the workshop into a laboratory, and art into a science. The search for a rigorous and accurate method to depict reality made many painters become the first scientists of the modern age. Some of the most famous of them were absolutely familiar with mathematics. Indeed, it is well known that many of those artists established relationships with mathematicians not by chance. In fact, they did it in order to secure the method used to depict 
reality (Dubourg Glatigny 2007, pp. 67-79). These cases include, among others, Piero della Francesca (1415-1492), educated as a mathematician, who defended the importance of measurements and wrote a text about this matter: De prospectiva pingendi. Leonardo da Vinci (1452-1519) also took an interest in mathematics and the accuracy of measurements, not for nothing did he draw the five Platonic solids for the book De divina proportione written by the Franciscan Luca Pacioli (1447-1517), and since 1497 he embarked upon the study of Elements by Euclid (Kemp 2006, p. 71 ss.).

It was the Renaissance physicians, philosophers, authors and painters, from Paolo dal Pozzo Toscanelli (1397-1482) and Biagio Pelacani (1355-1416) (Belting 2011, p. 146), to Brunelleschi and Leonardo, who conquered for arts, and in particular for painting, a liberal statute similar to that of the art of language, allowing them to sign their works. This conquest was unthinkable and unimaginable even to Zeuxis or Phidias. As we know, the latter was judged and jailed for impiety, because he had accepted that his portrait was sculpted by way of signature on the shield of the statue of Athena at the Parthenon. The Renaissance painter was not just a worker anymore, not even a craftsman, but someone that could scientifically guarantee the depiction of reality. There are few words more correlative with Modernity than guarantee, evidence and certainty. Artists conquered certainty by means of a mathematical technical procedure that was apparently infallible. Finally, the perspective, or construzione legittima, could guarantee the objects in mathematical space, by making them available to knowledge. This rigorous construction, based on geometry and mathematics, exerted an unrivalled magnetic fascination on the society of its time. So said Pelacani:

"Mathematical knowledge offers the maximum level of security and is superior to all other sciences, both in terms of knowledge and demonstrative elegance". "One single demonstration in geometry provides more knowledge than the entire natural philosophy" (Belting 2011, p. 146).

The combination of mathematics and geometry probably cast the same spell over Pelacani and over the author of The Divine Comedy. As we know, when he described the arts of the trivium and the quadrivium, he asserted that "geometry is brilliant white, since it has no trace of error, and is extremely accurate per se and because of its servant, known as perspective" (Dante 2006, II, xiii, p. 27). The versatile Leon Battista Alberti-who according to Vasari was "a great arithmetician and geometrician" (Vasari 2002, p. 315)—did not lag behind and in his Treatise on painting, he asserted that without the mastery of Geometry it is impossible for the painter to reach a level of solvency and perfection.

"I have said that I would like that the Painter was instructed in sciences; however, his main instruction must be in Geometry. ( . . . ) Indeed, the first rudiments of Painting are easily understood by the Geometrician; ( . . . )" (1980, p. 252).

Since then, painting had much to do with the intellectual and scientific activities. It was not just a servile or manual activity, it was quite liberal since it was strongly influenced by the head, as Michelangelo would say: "si pinge col cervello, non colla mano" (De Bruyne 1951, p. 180). The invention of a rigorous method, based on mathematics, allowing for the placement of objects of reality in space, by facilitating their depiction with high fidelity to reality, is what enabled the alignment between painting and science. Depiction could be mathematically evidenced, which is why "the appropriation and re-elaboration of the apprehensible reality" was rigorously guaranteed (Gehlen 1994, p. 52). Does this mean that at the dawn of Modernity the mastery of perspective and depiction of reality became the starting point for the experimental analytical sciences? If we understand as a science the observation with no prejudices of natural appearances, the measurement and the apprehension of its laws, the theoretical reflection of such knowledge, the explanation of how that experience takes place in the conscience, and the method capable of guaranteeing the identical reproduction of results, the answer is yes. Additionally, the fact is that what many of the Renaissance artists did was science, and as we have already stated, their modus operandi extended to other disciplines and areas of knowledge. This is precisely why Gehlen says that he finds understandable "the extraordinary fascination that emerged from 
the studies on perspective: in that conjunction, ( . . ) the idea of an exact science was firstly and fully formulated, when it had not been presented in any other place yet" (1994, p. 56).

As we have already stated, the desire for certainty and correctness, for accuracy and metric quantitivity, would be initially satisfied with perspective, and then it colonized many areas of knowledge and thought, such as anatomy, astronomy, biology, ontology, physics and philosophy, among others. The prevalence granted to sight as the primordial and exclusive form of knowledge was used by, among others, Alberti in Anuli and Leonardo in his Treatise on Painting.

"Corona et laetitie et gloriae insigne est: oculo perentius nihil, velocius nihil dignius nihil: quid multa? Ejusmondi est ut inter membra primus, praecipuss, et rex, et quasi deus sit. Quid quod deum veteres interpretantur ese quidpiam oculiu simile, universa spectantem, singulaque dinumerantem?" (Jarzombeck 1989, p. 11)

"Music cannot be called otherwise than the sister of painting, for she is dependent upon hearing, a sense second to sight ( . . ) ¡Oh marvellous science! ( . . )". " (.. ). The most honourable thing is that that satisfies the best sense. Therefore, painting, which satisfies the sense of sight, is nobler than music, which only satisfies hearing" (Da Vinci 2016, pp. 66, 68).

These are quite illustrative sentences that reveal a cultural paradigm based on the authority of sight, which will not disappear until the late 19th century and the early 20th century, when the principles of unpredictability (Planck), incompleteness (Gödel), unconscious (Freud) and uncertainty (Heisenberg) make modern certainties teeter.

Everything remains subject to an individual, whose vision becomes the determining fact, the centre of gravity that transforms reality and the world into an object. An individual before an object is the great conquest of this period: the "objectification of the subjective", as Panofsky would say (1991, p. 66). Even so, the desire for certainty and accuracy, the priority given to the point of view of the individual, the univocal and rigorous method that allowed capturing the reality, while measurable and representable, would shut out the very qualities of things, their symbolism and a great many aspects of reality that are not measurable or quantifiable because they lack extension. This is precisely why that scientific attitude, based on the guarantee, the measurement, and in particular, the priority given to sight, was what led to the devaluation of the sacred. That entire religious, spiritual and salvific world that had been founded on listening to the word of God, on the contemplation, adoration and devotion of the cult images "full of grace and holiness" (Uspenski 2013, p. 136) gave ground to the erection of the point of view of the transcendental subject that became the sovereign point of view, as if it was the point of view of the eye of God. Chueca Goitia reminds as follows: "Perspective implies the contemplation of the world from a single point of view, from a single eye that encompasses the entire panorama. This is a demonstration of human power, of the power of the prince" (Chueca 2013, p. 146). Florenski is more conclusive, and determines that perspective, more than reporting an absolute sovereignty, reports an isolated singularity and an individual concience, completely incapable of representing an eternal and gloriuos reality pierced by Grace.

"When the religious stability of a Weltanschauung disintegrates and the sacred metaphysics of the general popular consciousness is eroded by the individual judgement of a single person with his single point of view, and moreover with a single point of view precisely at this specific moment-then there also appears a perspective, which is characteristic of a fragmented consciousness." (2002, pp. 208-9).

After the Renaissance, during the age of western absolute monarquies, the rigour of the visual method was so strict that, as Ortega said, the attitude of the painter became extremely despotic. It was probably influenced by the close association of painters and mathematicians that, from Alberti, was so usual among the Renaissance artists, and that already in the Baroque was extremely consolidated, since-as Vasari said_- "art combined with science becomes something much more perfect and richer" $(2002, \mathrm{p}$. 314). That is precisely why Ortega, when he refers to Las Meninas ${ }^{3}$ 


\section{Perspective and the Decline of Gold}

The presence of gold was quite usual in many paintings of the Late Middle Ages (Valero-Cuenca 2011, pp. 13-19), especially in many of the Byzantine icons and in many High-Gothic panels. As a material, gold is unrivalled; not in vain Florenski remarks that "gold is completely alien to all paints" (2000, p. 121). Gold was used to emphasise that the icon "is executed upon light" (Florenski 2010, p. 136), to mark that that light was "the space of true reality" (Florenski 2010, p. 137), to dignify outfits (Belting 2021, p. 15) and to highlight the sanctity of characters by means of a halo (Belting 2021, p. 130; Uspenski 2013, p. 184) to show the sacrality of the scene or the part of the body that interceded with the divine and enabled the miracle (Belting 2021, pp. 58, 118) or, simply, as a neutral background in the form of a supernatural, ineffable and aniconic apeiron (Belting 2021, p. 102).

Gold is not a colour, but a material: it is the most perfect material, the most durable, the most incorruptible, the most yieldable, the most long-lasting (Eliade 1978, p. 142 ss.). Its use has much to do with these properties, which have been used by the artists of almost all times to depict, in an extremely plastic and symbolic manner, the spiritual, the eternal, the bright and the glorious. Gold is the material that best represents the shining of the sacred and transcendent; indeed, this material is absolutely consistent with and suitable for acts of worship relating to the Eucharistic celebration, adoration and contemplation: "The icon begins with the gold of creative grace, it ends in the highlighting with the gold of illumination, ssist" ( . . . )" (Florenski 2010, p. 137).

Moreover, gold is a very suitable material to separate the figures in any background or temporal landscape. With the use of the golden background, or pure and open background, (Uspenski 2013, p. 199), artists tried to locate figures in a transcendent, absolute and eternal dimension, extremely creatively, characterized by the active present that moves towards what is timeless (Belting 2021, p. 236), i.e., by the concept of "today" and by the concept of "I am": "( . . ) today you will be with me in Paradise" (Luke, 23, 43); "Today in the town of David a Saviour has been born to you (... )" (Luke, 2, 11); "I am who I am" (Exodus, 3, 14).

As we know, the creation ex novo of so many cities during the late Middle Ages and the advent of Modernity brought the transition from the vita contemplativa to the vita activa (Arendt [1958] 1998, pp. 277-86). The close and temporal, the earthly and worldly, the urban and civil are as related to the end of the Middle Ages and the modern world as the separation and the contemptus mundi were related to a great part of the medieval period. If thanks to the golden backgrounds, without any depth, artists managed to send the characters and spectators to what Benjamin called "the unique apparition of a distance, however near it may be" (2002, pp. 104-5), to a kingdom without time and space, with the modern landscape and urban backgrounds, Renaissance artists placed them in the "closeness" of the worldly and temporal context. With the gradual abandonment of gold and with the enhancement of the spatial and geometric depth, there was a transition from the depiction of the transcendent and contemplative to the scientific depiction of the world. So, the spectator was invited to contemplate the images from a perspective that was earthlier rather than more spiritual, and more temporal rather than eternal. Or, in other words: through gold, icon- and cult-images painters manifested that light conceived and created the world, which was its objective reason (Florenski 2010, p. 150). On the contrary, for the modern artist, things, instead of being created by light, just look to be illuminated from the outside. (Florenski 2010, p. 149).

The disuse of gold, which was eventually relegated to the frame of pictures (Baxandall [1972] 1988, p. 15), is also due to other factors that we would like to highlight and that are quite illustrative for the purposes of this paper.

Firstly, urban and active life enhanced the commercial mentality. The revaluation and economic investment in works of art, considered as consumer goods, and objects for display and collection, were not the result of the richness of materials, but of genius and authorship. Alberti is quite illustrative when he says in his Treatise on Painting that gold is not determining at all: "There are some painters that use gold indiscriminately, since they 
think that the abundance of gold gives majesty to their painting" (Alberti 1980, p. 249). In this respect, we could say that the author's signature and marks are even more important than the presence of gold. Additionally, here, we must understand "author" as the person capable of creating a work with extreme ingenuity, skills, expertise and grace, words that are tirelessly repeated by Alberti in the Treatise on Painting or Vasari in his Lives. About Brunelleschi, he says that "his mind simply imagined and plotted ingenious and difficult things" (2002, p. 255). About Leonardo, he says that "he had a more than infinite grace in any of his actions" (2002, p. 471). About Uccello, he says that "he was gifted with sophisticated ingenuity" (2002, p. 220), and so on and so forth. Thus, not with gold, but with ingenuity, grace and mastery (Baxandall [1972] 1988, p. 23) a work of art could be indefinitely revalued. Skills and genius always yield, they are never exhausted, they are immortal, they do not perish or go out of fashion from the commercial point of view, and they are a good investment. So Baxandall says: "As the conspicuous consumption of gold and ultramarine became less important in the contracts, its place was filled by references to an equally conspicuous consumption of something else: skill" (1988, p. 15).

Secondly, geometry prevailed over symbolism. Golden backgrounds and symbolic timelessness, we could say, the lack of temporal and spatial contextualization of Christian panels gave ground to a scientifically unprecedented manner to depict reality: perspective. It was not necessary to wait until the 20th century, the time of technical reproducibility of works of art, to observe the decline of the sacred aura. It was sufficient to witness the process of desacralization of reality, which took place when the world was left to the whims of the subject's gaze. The methodological and geometric rigour, the demand for accuracy and certainty, the conquest of which allowed to secure the depiction of reality, were more precious than gold. Consequently, strangely enough, ostentation and richness of gold lost relevance due to the presence of pavements ${ }^{4}$ or tiling, often chequered, of the structural beam layout, and of paddings and panels of vaults that made good use of the rigour and mathematical accuracy of depiction. With these graphic resources (pavement, panels, paddings, etc.), the rays of the visual pyramid were simulated, objects were stabilized, and painters made the anthropocentric gaze exert its absolute control over the world. The covert presence of visual rays allowed for the proper location of things in their real and empirical place, based on reliable and nonapparent specific measurements: "Certainty about objects results only when they have a calculable location in space" (Belting 2011, p. 34). This certainty is what was intuitively offered by Jean Pucelle (1300-1355) in the miniatures of the book The Hours of Jeanne d'Evreux, or Giotto (1266-1337) on the frescoes of the Lower Basilica of Saint Francis of Assisi. They were those who prefigured the concept of scientific perspective. Less than one century later, there were lots and lots of geometric and representative resources to make present the methodology of a cognitive gaze. Here, we could highlight the innumerable amount of pictorial works, showing the vault panels or the pavement to that end, which relegated gold to the frames and to other quite secondary aspects: from the fake chapel in the Holy Trinity by Masaccio (1428), The Flagellation of Christ by Piero della Francesca (460-1465), the Miracle of the Desecrated Host (1467-1469) or The Nativity by Paolo Uccello (1435), the previous study of The Adoration of the Magi by Leonardo da Vinci (1481), to Christ Giving the Keys to St. Peter by Pietro Perugino (1481-1482) or The Marriage of the Virgin (1504) and The School of Athens (1510-1512) by Raffaello Sanzio, apart from the famous vedute of Urbino (1470), or the theatre perspectives by Ferrara (1520) or those that appear in Book II of the Treatise on Architecture by Sebastiano Serlio (1475-c. 1554).

Thirdly, the use of scientific perspective, the recourse to drawn pavement or to paddings, the visual appearance of the horizon line and visual rays and, thus, the existence of the point of view, the prioritization of mastery and authorship, and of skills, capacity and grace, simply enhance the subject and the author, in contrast to medieval symbolism and gold. With the scientific perspective, the maximum value is obtained when the point of view of the individual and singular author allows to assert that reality is a "there" from the subject, and not something independent of him. Paradoxically, Modernity 
pursued objectivity from the subjectivity of the point of view, that all in all, is that of the creator of works of art. Samuel Dresden was right when he said that that was precisely why - because the author is the subject that sees the world with his own eyes-the old authority of guild workshops could not be maintained any longer: "Despite all the art rules that had to be learnt and applied, it was at this time that the concept of artist with divine inspiration was developed, an artist that created works of art, as the god on earth that he could become" (Dresden 1968, p. 234).

\section{From the Sacred to the Religious}

The transition from the sacred to the religious experience was correlative to the replacement of the objective with the subjective experience. It is related to the transition from the cult value to the exhibition value that Benjamin talked about (2003, p. 52). In the subjective prevalence of the anthropocentric and modern religious experience, the invention of scientific perspective will have much to do with the erection of the point of view of the transcendental subject, considered as the only legitimate point of view. In the Middle Ages, neither eastern nor western, there was no scientific perspective or visual horizon line or illusion or fiction; there was reality. A reality, we could say, of a far-off and theophanic nature that only the holy scripture and the icon could represent: "The Holy Scripture and the holy image illuminate and explain themselves reciprocally. It is the same testimony expressed through two different ways: the word and the image. Both transmit the same revelation to light of the same sacred and vivid tradition of the church" (Uspenski 2013, p. 145). This is precisely why the cult image had a singularly theocentric, catechetical and testimonial, and, in particular, presence-based and immediate dimension. We could say that the medieval cult image had an epiphanic essence, since it included the maximum presence of reality. With the advent of the Modern Age and "the secular worship of beauty, which developed during the Renaissance" (Benjamin 2002, p. 105), the high aspiration of the medieval sacred image gives ground, loses its vital context (Sitz im Leben) and enters a period of aesthetic compensation, which is more artistic and exhibitionist, more creative and religious (Belting 2021, pp. 18, 26). That period could be characterized by the sociocultural existence of the desire to make the subject become the sovereign owner of the things seen in their purest closeness or objectuality.

We assume that during a great part of the medieval period, fascination with the visual imagen - faithful reflection of what could be seen-kept the validity of the old suspicion of the eidolon, of the apparent figures in mirrors, as Plato would say in Timaeus (2011, 46a, p. 83).

Much of this suspicion was due to the risk of idolatrous pleasure, which the Old Testament talks about. To a medieval man, the cult image could achieve what contemplation pursued, and it could satisfy the desire for plenitude embedded within the heart of man. Against the power of simulations that "have mouths, but cannot speak, eyes, but cannot see. They have ears, but cannot hear, noses, but cannot smell. They have hands, but cannot feel, feet, but cannot walk, nor can they utter a sound with their throats" (Psalm, 115, 5-7), the medieval icon enabled a type of reality or presence that can be looked at, above all, it could be perceived. Cult images were not just images to be seen, but to let them be seen. Belting was right when he said that "the icon represents the only gaze of which we could say that it is absolutely looking" (2011, p. 225).

During the Middle Ages, the way to have access to the truth of reality was not projective, but contemplative; it was not subjective, but objective, just like the being and the work of God (Guardini 1960, p. 18). To a medieval faithful man, as Zambrano would say, reality is not only "the reality that has been captured and defined by the thought, but that other reality that remains indefinable and imperceptible, that reality that surrounds the conscience and highlights it as an island of light in the middle of the dark" (2019, p. 227). Moreover, that attitude and manner to face what was maximally real did not befit only the concept of seeing or doing or saying, but taking, we could say, the attitude of someone who is being touched by a kind of presence that has made its own way through the work 
and liturgy, and however it is none of them, strictly speaking. We can use few words to describe this situation where the subject, instead of understanding the meaning, captures and perceives the sense. Yes indeed, what becomes present through the work is not the reason of reality, but the sense, something that is only captured when the being of reality, or ultimately God, is offered, given and delivered in his manifestation. God is given; the being is delivered.

The being is given, is delivered, and then it appears open in his manifestation. That is precisely why, during the Middle Ages, there is not any place from which one could look or any primordial point of view that the subject could use, there is no horizon or scenic background. There is pure depth and profundity, eternity visible for an instant, illumination and unveiling. To many authors, that was one of the tasks of gold, as we have stated above: to depict the aura and the remoteness, without which images could not be worshiped. That was also a task of the veil or curtains that hid the images from gazes. In certain liturgical celebrations, curtains were opened to unveil the presence that, according to the faithful, manifested in the cult image. Such an unveiling was perceived as a visible apparition of Christ, the Virgin or the Saints.

The experience of the sacred-so characteristic of the Romanesque and the Byzantine iconography - could not be understood if the concepts of mystery, symbol and, undoubtedly, invisibility were not admitted. 1. Mystery is not what can be understood, but what can only be contemplated. Mystery establishes a limit, not due to a lack, but due to overabundance. 2. We could say that the symbol is something that makes what it expresses (what it symbolizes) possible. 3 . The invisible would be what becomes present beyond the capacities of the subject. The mysterious, the symbolic and the invisible stress that God, as a being and as a reality, is an excess to reason, a scandal to senses that absolutely surpasses the intellectual and sensitive capacities. We owe to Scotus Erigena a definition of beauty, which coordinates these three concepts and stresses the absolute incapacity of the human and of the subject.

"Beauty is the Invisible becoming visible, the Incomprehensible becoming intelligible, the Unknowable revealing itself; that which surpasses all form appearing in a determined specific figure: Forma et specie carens seipsum faciens formosum et speciosum (What is formless making itself well-formed and beautiful)" (De Bruyne 2010, p. 95).

Beauty is not something that the subject can conquer from any point of view; it is not a merit or a title that can be attributed to the individual initiative, it is a gift that can be received and taken, but that cannot be caused. The strength of the medieval work and the icon does not only lie in their plasticity, but in enabling the advent of what is maximally real. In the Middle Ages, cult images were worshiped, but actually what the faithful did was to let themselves be touched by what took place through those images.

We reiterate that the sacred image has to do with that maximum or overabundance of being, and with that excess of reality that takes place not in a saying or an action of the human, but in letting oneself be touched in contemplation. As Guardini would say, cult images are related to this kind of experience that although unspeakable is not necessarily subjective, but rather maximally objective, metaphysical, ontological and, finally, real. About these kinds of images, it has been said that they have no psychology or interiority, but that they have reality and, in particular, authority (Guardini 1960, p. 24). The sacred, which becomes apparent in the works with no background and with no point of view of the spectator, gave rise to a kind of experience that took place beyond the meaning. The experience of the sacred was the experience of the sense, and that is why we can assert that it was maximally objective. However, it was an objectivity that transcended and exceeded the craftsman or artisan, by rendering their authorship irrelevant, and the spectator, by rendering his merits or virtues irrelevant. The only thing that is carried out by the artist of sacred images is a service, not a creation, and that is why it was superfluous to wonder who had created a specific sacred image. The cult image was not a work of the artist's fantasy or imagination. This can be surprising to us, the modern people, but to the medieval author the marks or traces of his authorship were absolutely irrelevant. His only mission was to 
enable-by means of his work — the prodigy of the manifestation of God: the Spirit of God. In this respect, Guardini was right when he said: "The man that creates a cult image is not an artist, as we understand it. He does not create, if we take this word as we normally use it, but he serves" (1960, p. 23). In that sense, the painter's artistic, thematic or technical free will has little or nothing to do. His professional genius, grace and virtue were absolutely secondary to his mission, which was no other than the mission to make the image acquire such an authority or power that its veneration was fully legitimate (Belting 2021, p. 207).

In summary, with the advent of the Gothic, of the resurgence of cities and trade and finally, of the dawn of the modern world, the first subjective forms of experience took place and started to remarkably differentiate from the cultic, sacred and objective period of art. That is the difference between the religious and the sacred. Hegel asserts it with great clarity on his Lectures on Fine Arts:

"Religion has pictorial thinking as its form of conscious ness, for the Absolute has removed from the objectivity of art into the inwardness of the subject and is now given to pictorial thinking in a subjective way, so that mind and feeling, the inner subjective life in general, becomes the chief factor" (Hegel 1988, p. 103).

Modernity, the exaltation of the ego sphere, the reduction of reality to what can be measured, the mathematization of space and of any visual reality, ended up reducing the magical, symbolic and sacred experience of the work of art. In other words: the rationalization of the sight as the supreme and exclusive form of knowledge implied the desecration of the sacred. The desire for certainty and accuracy, which the legitimate construction made possible, gave rise to a first stage of demystification of reality. The work of art could not produce what it meant anymore or symbolize what was symbolized. Perspective granted the exact measurement and the accurate position to the beings and figures that the human eye saw, and that was the excellence of the point of view. However, at the same time it stripped the work of the possibility of the miracle, i.e., of its manifestation and testimonial (Panosfky 1991, p. 72). The immediate character of the sacred, which once took place in the manifestation and unveiling of what was ontologically diverse ${ }^{5}$, was cancelled in the scope of the exact and rigorous representation of the subjective point of view. The supernaturalization of the experience caused by the overabundance of reality produced by the sacred work started no longer to have place in the infinite homogenization of a constant and isomorph space that the perspective science, based on mathematics, had achieved. The objectivity of the method, the exaltation of authorship and the individual point of view, closed down the access to the superobjectivity and sacramentality implied by the symbol and the sacred cultic image.

\section{Conclusions: Sanctity as a Cult Image. The Distant in the Close}

In the Modern Age, the experience of the sacred declined. Many of the advances, discoveries and inventions favoured what Weber called the disenchantment of reality. Then, a slow but steady process of incapacitation or fatigue took place for the sacred, the mysterious and the symbolic. The modern man was not interested in mysteries, but in secrets. His attitude-a detective attitude, we could say-was typical of a person that wanted to transform reality into a measurable, quantifiable and reproducible object. Life in the city and the priority of action over contemplation had much to do with this process. The presence of God experienced before cultic images, in particular during the liturgy, gave ground to a kind of experience that was originated from the subject, from the human spirit, we could say. Guardini did not doubt it, when he verified the transition from the cult to devotion, and that is why he asserted that "while the cult image is aimed at transcendence, or more precisely, it seems to come from transcendence, the devotional image emerges from immanence, from interiority" (1960, p. 20). This resulted in a sort of devaluation of the experience that, since it was originated from the subject, could only show the subjective experience of God, but not of the divine reality that any sacred experience implies. The individualization of this experience was the correlate of the exaltation of the subject and of the individual point of view in the religious and spiritual sphere. The religious experience 
was no longer the experience of reception, but the experience of creation or action. It made sense that the work of art, which expressed the way in which the subject was affected by divinity, had authorship. The image gave way to the work. It was no longer a service, but an expression, a demonstration. The personality of the subject that represented his divine experience started to become extremely important. In modern religious and devotional works, authors discussed how sacred things affected and addressed the subject. It was the man who spoke, not God (Guardini 1960, p. 22).

Guardini senses the danger in this transition from the sacred to the religious. He does not hide his preference for the cultic imagen. He suspects that the religious work or the devotional image, since they are born to the individual, are subject to all mistakes, uncertainties and insecurities typical to any subjective creation that is placed over the objectivity of the being and the divine act. He thinks that the religious is less dense because it is the work of the subject and not the manifestation of God. The objectivity of the cult image, its universal validity, and the meaning that could be captured by the person that was touched by the manifestation of God, which took place in that image, was replaced with the subjectivity of the personal experience from which the artistic creation emerged.

So, if the objectivity took place in the sacred image and the only thing that the devotional image could represent was a subjective experience, we consider that there is no room for discussion. The hierarchy of the former over the latter seems unquestionable. The person that is touched by the presence of God in the cult image captures more reality than the person that is moved before the religious image, no matter how skilful, adroit and perfect its execution may be. According to Guardini, Andrei Rubliov would win in his impersonal action, which is a service, because he makes something possible that neither the individuality nor the expertise of Leonardo or Michelangelo can offer. In the cult image, the artist disappears as the intermediary, while in the devotional or religious image he is always present, as the creator or interpreter. Florenski and Uspenski conclude as follows:

"(an) icon is never conceived as an act of solitary creativity; rather, every icon belongs in essence to the collective work of the Church" (Florenski 2010, p. 134)

"The orthodox church has never allowed icons painted following the imagination of the painter or a living model. That would mean the total ruptura with the prototype" (Uspenski 2013, p. 178)

Nevertheless, what the religious image might be does not seem to be reduced to a simple expression of a subjective experience. It is well known that many of the great Renaissance artists were not models of virtue or examples of sanctity. The lives of Rubliov and of Leonardo cannot be compared in this respect. However, what we want to highlight is that what the modern artist looks at and watches is not God in the objectivity of his being and works. Rather, the artist looks at the sanctity of the person that represents. Additionally, here, we must understand "sanctity" just as the triumph of Christ in the souls. A saint is someone that has accepted to be touched by the love of God, by emptying himself absolutely and by filling himself up with Christ. A saint is a subject within whom there is another person living, Christ, so that that other person is not the origin of his life anymore, but the very God. Saint Paul asserted it quite clearly: "It is no longer I who live, but Christ who lives in me" (Gal., 2, 20). The modern artist that creates devotional images does not depict his personal experience with God only, but also the life of the saint, a living icon, since God becomes visible in the latter.

Moreover, between the religious artist and the saint there is a great similarity with regards to their actions. As we have stated, during the Middle Ages there were no artists, but authorities. The influence of guilds was decisive regarding the production of images and works of any kind. The standards and rules that guaranteed the production of the author were applied, without there being much room for interpretation. The authority of guilds was similar to that of censors that checked whether a work adapted or not to the precepts of trade. In the activity of guilds, there was no freedom for the author, strictly speaking. So, the person that executed a work was not present as its author. This 
corresponded to the guild, or the collective author, we could say. For the existence of an author, it is necessary that there is the possibility of authorship, i.e., the possibility that the creator can leave the mark of his individuality on what he creates, so that he can be recognized in his work. Indeed, the author of the first Modernity does not correspond in any way to the author of the 20th century avant-gardes. Additionally, this happens, because the freedom of those authors did not cancel or conceal the standard or the rule. In the freedom of action of many of those artists, there was an interpretation of the rule that did not hinder their recognition; however, his singular and individual interpretation was recognizable. The artist and author was not the person that cancelled the rule, but rather the person that made it brighter, because he interpreted it as if he was at the time of its creation. This singular interpretation process might well be called "style". So, in the religious scope, the saint would be the correlate of that modus operandi that makes personality visible, but does not override the rule or the standard, but that takes it to full applicability. A saint is not only the faithful subject to the rule, the precept or the content of revelation, but also he who interprets all the foregoing in such a way that God becomes visible in him, by highlighting any aspect that was not so perceptible in the mere revelation. The saint was he who had acquired an aura, as if he were a "living icon" (Belting 2021, p. 86). The work of art would be what they have managed to do with their own life, and the last author of that work would be the Spirit of God. We insist, the essence of sanctity is the reproduction in a man of the face of God.

Although, strictly speaking, there are not any sanctity styles, there are peculiar gifts that serve the good of the Church, for its renovation and, undoubtedly, for the common good. Saint Paul asserted it as follows: "Now there are varieties of gifts, but the same Spirit; and there are varieties of service, but the same Lord; and there are varieties of activities, but it is the same God who empowers them all in everyone" (1 Cor., 12, 4-6). In that sense, there are saints that have stood out due to their evangelical interpretation of poverty, of the works of mercy, of work, of the guidance and support of souls, etc. Saints are the most original and different beings ever. In a way, they are a spectacle that is worth seeing, as St Luke would say. It is apposite to bear in mind that St. Pius V, St. Philip Neri, St. Ignatius of Loyola and St. Charles Borromeo lived in the Rome of the 16th century. They lived in the same city, at the same time and in the same cultural period and, however, they were absolutely different from each other, although the essence of their sanctity is the same. Each of them make the face of God visible, but they do not do it because they decide to do it somehow or other, but because the Spirit works in them in a diverse manner. We could say the same about St. Teresa of Jesus, St. John of the Cross, St. Peter of Alcantara, St. Francis Xavier and St. Francis of Borja. All of them lived in the Spain of the 16th century, however they are quite different and original. What the Spirit decides to do is what the saint can be. Additionally, that is the life and the face that the artist depicts in his work, the work of God in a man: a "living icon". That is why the devaluation resulting from considering a devotional or religious work as a simple work created by the hands of the artist, from his point of view, is incomplete. Additionally, this is because the model of the artist is the spectacular life of those who have made God visible. In our opinion, the life of saints has much to do with cult images, since God manifests through them. Thus, what the artist carries out is not only a singular and subjective interpretation of his experience with God, but the depiction of a maximally subjective and original interpretation: the life of a saint. Perhaps that is why the devotional image is just actually a cult image, while what is depicted is the activity of the Spirit that has manifested in the human work of saints.

Funding: This research received no external funding.

Institutional Review Board Statement: Not applicable.

Informed Consent Statement: Not applicable.

Data Availability Statement: Not applicable.

Conflicts of Interest: The author declares no conflict of interest. 


\section{Notes}

1 “a polyphonic expressiveness" (Florenski 2010, p. 136).

2 "The eye is the symbol of joy and glory, and it is more powerful than anything else: what more can I say? It is such as to be the first, chief, king, like a god of human parts. Why else did the ancients consider God as something akin to an eye, seeing all things and distinguishing each separate one?". Alberti, Leon Battista, Anuli, pp. 229-30, quoted by (Jarzombeck 1989, p. 11).

3 Although Las Meninas does not correspond to the Renaissance, but to the Baroque, it is—in our opinion-one of the most illustrative examples to synthetize a great part of what we have asserted on this paper. It is a work where the painter appears painting, because painting has become thematic. The painting activity assisted by geometry and mathematics allowed the painter to climb the social ladder. It was not a servile task anymore, but rather liberal. On the other hand, Velázquez appears on the picture gazing at or watching reality. The points of view of the author and of the spectator appear in the picture, which enhances the centrality of the gazing subject in the depiction of reality., to Las Hilanderas [The Spinners], and, undoubtedly, to Las lanzas [The Lances] by Velázquez (1599-1660), tells us that the painter from Seville: “( . . ) decides to despotically fix the point of view. The whole picture will be born from a single vision act, and things will have to strive to reach the visual ray" (2016, p. 201).

4 See Karsten Harries' comment on the work of Roger van der Weyden, Saint Luke Drawing the Virgin, 1435. (Harries 2001, pp. 89-90).

5 To reflect on the sacred in a sense that is ambivalent, saint and damned, that attracts and repels at the same time, (Agamben 2006).

\section{References}

Agamben, Giorgio. 2006. Homo Sacer. El Poder Soberano y la Nuda Vida. Valencia: Pre-Textos.

Alberti, Leon Battista. 1980. Los tres Libros de la Pintura por Leon Bautista Alberti. Murcia: Colegio de Aparejadores y Arquitectos Técnicos de Murcia.

Arendt, Hannah. 1998. The Human Condition. Chicago and London: The University of Chicago Press. First published 1958.

Aristotle. 2009. The Nicomachean Ethics. Oxford World's Classics. Oxford: Oxford University Press.

Aristotle. 2019. Metaphysics. Book Lambda. Oxford: Oxford University Press.

Arnau, Joaquín. 1987. La teoría de la Arquitectura en los Tratados. Vitruvio. Madrid: Tebar Flores.

Baxandall, Michael. 1988. Painting and Experience in Fifteenth Century Italy. A Primer in the Social of Pictorial Style. Oxford: Oxford University Press. First published 1972.

Belting, Hans. 2011. Florence and Bagdad. Renaissance Art and Arab Science. Cambridge, Massachusetts and London: Harvard University Press. (First published: 2008, Florenz und Bagdad. Eine westöstliche Geschichte des Blicks. München: Verlag C.H. Beck).

Belting, Hans. 2021. Imagen y culto. Una historia de la imagen anterior a la historia del arte. Madrid: Akal. (First published: 1990. Bild und Kult. Eine Geschichte des Bildes vor dem Zeitalter der Kunst. München: C.H. Beck).

Benjamin, Walter. 2002. The Work of Art in the Age of Its Thecnological Reproducibility. En Selects Writings. Cambridge, Massachussetts and London: The Belknap press of Harvard University Press, vol. 3, pp. 1935-38. (First published: 1936. Das Kunstwerk im Zeitalter Seiner Technischen Reproduzierbarkeit, Zeitschrift für Sozialforschung).

Burckhardt, Jacob. 1966. The Civilization of the Renaissance in Italy. Viena and London: The Phaidon Press.

Chueca, Fernando. 2013. Breve Historia del Urbanismo. Madrid: Alianza Editorial.

Da Vinci, Leonardo. 2016. Tratado de Pintura. Madrid: Akal.

Dante. 2006. Convivio. Madrid: Ediciones Cátedra.

De Bruyne, Edgard. 1951. Geschiedenis van de Aesthetica. De Renaissance. Amsterdam and Antwerpen: Genaaid en gebrocheerd.

De Bruyne, Edgar. 2010. La Estética de la Edad Media. Madrid: Antonio Machado libros.

de Cusa, Nicolás. 2009. La visión de Dios. Pamplona: Eunsa.

de Libera, Alain. 2015. L 'invention du Sujet Moderne: Cours du Collège de France 2013-2014. París: Vrin.

Dresden, Samuel. 1968. Humanism in the Renaissance. New York: Weidenfeld \& Nicolson.

Dubourg Glatigny, Pascal. 2007. La Perspectiva en el siglo XVI. Textos, Documentos de Historia y Teoría. Halshs-02957645. Bogotá: Universidad Nacional de Colombia, pp. 67-79.

Eco, Umberto. 1992. El Nombre de la rosa. Barcelona: RBA Editores.

Eliade, Mircea. 1978. The Forge and the Crucible. Chicago: University of Chicago Press. (First published: 1956. Forgerons et al.Chimistes. París: Flammarion).

Euclides. 1945. The Optics of Euclid, Translated by Harry Edwin Burton. Journal of the Optical Society of America 35: 357-72.

Florenski, Pavel. 2002. Reverse perspective. In Beyond Vision. Essays on the Perception of Art. Reaktion Books. London: Nicoletta Misler.

Florenski, Pavel. 2010. Iconostasis. New York: SVS Press.

García Sánchez, Rafael. 2020. Belleza Sapiente. El Agrado de la Mente. Pamplona: Eunsa.

Gehlen, Arnold. 1994. Imágenes de Época. Sociología y Estética de la Pintura Moderna. Barcelona: Península, (First edition: 1960. Zeit-Bilder. Zur Soziologie und Ästhetik der Modernen Malerei. Frankfurt Am Main and Bonn: Athenaum Verlag).

Guardini, Romano. 1960. Imagen de culto e Imagen de Devoción. Sobre la Esencia de la obra de arte. Madrid: Ediciones Guadarrama. (First published: 1936. Kultbild und Andachtsbild. Würburg: Werkbund-Verlag).

Harries, Karsten. 2001. Infinity and Perspective. Cambridge: MIT Press.

Hegel, Georg Wilhem Friedrich. 1988. Aesthetics. Lecture on Fine Arts. New York: Oxford University Press.

Hegel, Georg Wilhem. 1989. Lecciones Sobre la Filosofía de la Historia Universal. Madrid: Alianza. 
Heidegger, Martin. 2018. "La época de la imagen del mundo" en Caminos de Bosque. Madrid: Alianza Editorial. Heráclito. 2008. Fragmentos Presocráticos. De Tales a Demócrito. Madrid: Alianza editorial.

Jarzombeck, Mark. 1989. On Leon Baptista Alberti: His Literary and Aesthetic Theories. Cambridge: MIT Press.

Kemp, Martin. 2006. Leonardo da Vinci. The Marvellous Works of Nature and Man. New York: Oxford University Press.

Lindberg, David. 1976. Theories of Vision. From Al-Kindi to Kepler. Chicago and London: The University of Chicago Press.

Lindberg, David. 1983. Study in the History of Medieval Optics. London: Variorum Reprints.

Lindberg, David. 1996. Roger Bacon and the Origins of Perspectiva in the Middle Ages. Oxford: Clarendon Press.

Lortz, Joseph. 2008. Historia de la Iglesia II. Edad Moderna y Contemporánea. Madrid: Ediciones Cristiandad.

Manetti, Antonio. 1976. Vita de Filippo Brunelleschi. Milano: Il Polifilo.

Maritain, Jacques. 2006. Tres Reformadores. Lutero-Descartes, Rousseau. Madrid: Encuentro.

Morris, Colin. 1972. Discovery of the Individual: 1050-200. Londres: SPCK.

Ortega y Gasset, José. 2015. Meditación de la Técnica. Ensimismamiento y alteración. Madrid: Biblioteca Nueva.

Ortega y Gasset, José. 2016. La deshumanización del arte. Barcelona: Espasa.

Panikkar, Raimon. 2008. De la mística. Experiencia Plena de la vida. Barcelona: Herder.

Panosfky, Erwin. 1976. Gothic Architecture and Scholasticim. New York, London and Scarborough: A Meridian Book.

Panosfky, Erwin. 1991. Perspective as Symbolic Form. New York: Zone Books, (Originally published as "Die Perspektive als "symbolische Form"'", in the Vorträge der Bibliothek Warburg 1924-1925 (Leipzig\& Berlin, 1927), pp. 259-330).

Pernoud, Régine. 2010. Para acabar con la Edad Media. Barcelona: Medievalia, (Firts edition:1977. Pour en finir avec le Moyen Age. París: Éditions de Seuil).

Plato. 2008. Timeaus and Critias. Oxford World's Classics. New York: Oxford University Press.

Putallaz, Francois-Xavier. 1991. La Connaissance de Soi Au Xiie Siecle: De Matthieu d'Aquasparta a Thierry de Frieberg. París: Etudes de Philosophie Medievale. Vrin.

Uspenski, Leonid A. 2013. Teología del icono. Salamanca: Ediciones Sígueme, (1980, La Théologie del 'icône dans l 'Église orthodoxe. París: Les Éditions du Cerf, 1980).

Valero-Cuenca, Aurora. 2011. El oro: Símbolo de lo trascendente en la pintura gótica. Su capacidad como elemento transformador, espiritual y plástico. Archivo de Arte Valenciano V: 13-19.

Vasari, Giorgio. 2002. Las Vidas de los más Excelentes Arquitectos, Pintores y Escultores Italianos desde Cimabue a Nuestros Tiempos. Madrid: Cátedra, (1986 and 1991. La Vite de 'piú Eccellenti Architetti, Pittori, et Scultori Italiani, da Cimabue, Insino a' Tempi Nostri. Torino: Giulio Einaudi editore).

Vitruvio. 1993. Los diez libros de Arquitectura. Barcelona: Editorial Alta Fulla.

Von Martin, Alfred. 1944. Sociology of the Renaissance. London: Karl Mannheim, (First edition: 1932. Soziologie der Renaissance, Germany).

Zambrano, María. 2019. El hombre y lo Divino. Madrid: Alianza editorial.

Zubiri, Xavier. 1980. Inteligencia y Realidad. Madrid: Alianza. 